\title{
The Correlation of Arm Muscle Explosive Power, Leg Muscle Explosive Power, and Hand- Eye Coordination Towards the Smash of Badminton Player
}

\author{
Febby Pratama \\ Master Degree of Sport Education at Sport Science Faculty of Padang State University \\ Jl. Prof. Dr. Hamka, Air Tawar, Padang, Indonesia \\ Email: febbyagain@gmail.com
}

\begin{abstract}
This study aimed to investigate the degree of relationship among arm muscle explosive power, leg muscle explosive power, and hand-eye coordination towards badminton players of PB. Hamparan Sungai Penuh city. This study was a correlation research design. The population was badminton players of PB. Hamparan Sungai Penuh city, which joined the training for 25 people. The study showed some results as follows: 1 ) There was a significant correlation between arm muscle explosive power $\left(X_{1}\right)$ with $\operatorname{smash}(Y)$ of badminton player at $P B$. Hamparan Sungai Penuh city with $\mathbf{r}$ count $0,733>r$ table 0,641 dan $t$ count $=5,71>t$ table $=1.76$. 2) there is a significant correlation between leg muscle explosive power $\left(\mathrm{X}_{2}\right)$ with smash $(\mathrm{Y})$ of badminton players of $P B$. Hamparan Sungai Penuh city with $\mathbf{r}$ count $0,713>r$ table 0,641 dan $t$ count $=5,23>t_{\text {table }}=1.76$. 3) there is a significant correlation between hand-eye coordination (X3) with smash (Y) of badminton players at $P B$. Hamparan Sungai Penuh city with $r$ count $0,713>r$ table 0,661 dan $t$ count $=4,23>t$ table $=1.76 .4$ ) there is a significant correlation among arm muscle explosive power $\left(\mathbf{X}_{1}\right)$, leg muscle explosive power $\left(\mathbf{X}_{2}\right)$, and hand-eye coordination $\left(\mathrm{X}_{3}\right)$, with smash $(\mathrm{Y})$ of badminton players at PB. Hamparan Sungai Penuh city with $\mathbf{r}_{\text {count }} \mathbf{0 , 8 3 8}>\mathbf{r}$ table 0,641 dan $f_{\text {count }}=8,67>f_{\text {table }}=3,98$.

Keywords-Arm muscle explosive power, leg muscle explosive power, hand-eye coordination, smash, badminton
\end{abstract}

\section{INTRODUCTION}

Indonesia is a developed country which actively enforces its development in all fields. One of the developments is in all sports fields which aims to enhance the quality of a human being in order to be skilled, conversant, intelligent, good personality, sportsmanship, physically and mentally healthy for educating the life of Indonesia. The National Sports System is the whole aspect of the sport that is interrelated in a planned, systematic, integrated and sustainable manner as a whole that includes the regulation of education, training, management, guidance, development and supervision to achieve national sports goals"[1].

According to citation above, it implies that the aim of the national sport is facilitated through development and guidance which is carried out in a planned, systematic, continuous and integrated. Besides, supervision and management of training are truly needed in its implementation and well-formed education in order to pursue certain achievement. One of the most popular sport for people is badminton. Badminton is sports which are quite popular for society in the world especially Indonesia. It is proven by high enthusiasm of society in participating badminton competition whether in local level or world level such as Thomas/Uber cup and Olympic. Badminton is either played by children or adults in indoor or outdoor. There are some coaching efforts for each sports organization in every region to increase sports' achievement, badminton is one of the fields. Sports Coaching and development have become the responsibility of all elements, either in center organization or district. The main organization in center and region must be hand in hand to empower and guide the sports so that it can reach prestigious sports' achievement such as badminton's achievement.

Good games can be formed while supported by physically, technically, strategically, and mentally well. "The better physically of one, the better the output of him". Meanwhile, [2] argued: "Improvement in athlete's physical condition aims to increase physical power in order to support sport activity for reaching better performance". It can be implied that physical condition is fundamental in a sport particularly in badminton games. There are some variations of punch in badminton game such as service, lob punch, smash, drop shot, drive, and netting play, all punches have their own purposes, different move and its implementation depending on the needed physic. Smash is a punch which is deadly move in a badminton game, this punch is done hardly, quickly, strongly to shut off the shuttlecock under the opponents' area. Those variations above, the most essential strategy for players to be mastered is a smash. Smash is a key to shut off the shuttlecock to the opponent in badminton. The characteristics of this punch are strong, swoop sharply, and also smash at correct time and direction to the opponent. In this game, every punch needs a complex movement. "every smash requires the power of leg muscle, shoulder muscle, the explosive power of leg 
muscle, the explosive power of shoulder muscle, arm muscle strength, arm muscle explosive power, wrist flexibility, waist flexibility, and harmonically body movement coordination [3]. Reaching a maximum achievement in badminton requires some influential factor such as smash accuracy. Smash is an important element that must be mastered by badminton player to get points. Some factors influence smash accuracy of an athlete for instance arm muscle, leg muscle, and hand-eye coordination. Explosive power of muscle is a combination of some physical elements such as strength and speed. It means explosive power can be seen from the response of the body which used strength and speed. For example, the form of leg muscle explosive power is jumping, the form of arm muscle explosive power is a throw and hand-eye to direct. A badminton player must have good coordination which usually performs the beautiful and rhythmic movement. The movement does not seem stiff and uninterrupted. But, it is organized and done sequentially well as it should be. Therefore, coordination means the ability to string some movements to be aligned and in accordance with the purpose movements. Speed means the ability of someone to move from one spot to another spot in the shortest time. A badminton player must be able to return the ball quickly which hit by the opponent if the player is able to set the hit position. According to [4] stated that "Flexibility is one of physically elements in mastering movement skills, preventing injury, developing strength skill, speed, endurance, agility, and coordination."

Increasing smash must be exercised perfectly so that reaching maximum achievement. If physically condition elements such as arm muscle explosive power, leg muscle explosive power, and hand-eye coordination are not well-trained, the player would feel difficult to perform strongly, quickly, swooping down, and right on target smash. In addition, $P B$. Hamparan Sungai Penuh city would decrease the achievement if the players do not concern and train smash accuracy. Smash in badminton game of PB. Hamparan Sungai Penuh city is truly needed to train specifically to enhance the achievements. Based on the direct observation in the field, there are some mistakes in doing smash done by badminton players at PB. Hamparan Sungai Penuh in their training. It causes the shuttlecock often positioned on the net and splay out of the field which gives advantage for the opponent. According to problems at PB. Hamparan Sungai Penuh city as stated above, the researcher is interested in conducting a study about the relationship of arm muscle explosive power, leg muscle explosive power and handeye coordination towards the smash of badminton player at "PB. Hamparan" Sungai Penuh city.

\section{RESEARCH METHOD}

This study was a correlational research design, which was arranged to see the relationship between an independent variable and a dependent variable. The study was organized to determine the level of variable relations which was different in a population, it was aimed to investigate the relations of the independent variable and dependent variable. The independent variable of the study was arm muscle explosive power, leg muscle explosive power, and hand-eye coordination. Whereas, the dependent variable was the smash in badminton. The study was taken place at PB. Hamparan hall RawangSungai Penuh. The date was conducted on 1-2 June 2013

The population of the study was all badminton players at PB. Hamparan Sungai Penuh which participated by 25 people.

\begin{tabular}{|l|l|c|}
\hline Group & Age & Total \\
\hline Beginner & 13 years lower & 5 people \\
\hline Teenager & 16 years lower & 3 people \\
\hline Young Adult & 19 years lower & 15 people \\
\hline Adult & 20 years upper & 2 people \\
\hline & Total & 25 People \\
\hline
\end{tabular}

According to population above, the technique of collecting the sample is purposive sampling which player was a young adult group in a total of 15 people who were active. Due to they were good enough physiologically which proper age for building physically, they were prepared to be a successful athlete. In this research, it requires primer data taken from a test for arm muscle explosive power, leg muscle explosive power, hand-eye coordination and smash of the players at PB. Hamparan Sungai Penuh. The test of arm muscle explosive power was done by using medicine ball, the test vertical jump was measured for leg muscle explosive power, ballwerfenund-forgen test for hand-eye coordination, and a test for smash to measure the hitting ability. To know the correlation between arm muscle explosive power and leg muscle explosive power through smash, thus the power produced would be analyzed by some statistics formula: multiple correlation and simple correlation.

\section{RESULTS}

\section{Normality Test}

Normality test was done by liliefors test for each frequency distribution. The result of arm muscle explosive power variable $\left(\mathrm{X}_{1}\right)$, arm muscle explosive power variable $\left(\mathrm{X}_{2}\right)$, hand-eye coordination variable $\left(\mathrm{X}_{3}\right)$, and smash variable (Y) the players of PB. Hamparan, Sungai Penuh, it can be listed on the table below: However, the analysis requirement of normality test is if Lo is bigger than Ltable, which means the population is not normal. But, if Lo is smaller than Ltable, it means the population distributed normally. The table above showed the result of normality test for arm muscle explosive power $\left(\mathrm{X}_{1}\right)$, score Lo $=0.1555$ with $n=15$. Meanwhile, Ltab on test level of significance $\alpha=0,05$ obtained 0,220 which is bigger than Lo, it means the obtained score distributed normally. The result of leg muscle explosive power $\left(\mathrm{X}_{2}\right)$, score Lo $=$ 
0.1664 with $\mathrm{n}=15, \mathrm{~L}$ tab on test level of significance $\alpha=$ 0,05 obtained 0,220 which is bigger than Lo. It means the obtained score distributed normally. The result of handeye coordination test $\left(X_{3}\right)$, score Lo $=0.1016$ with $n=15$, meanwhile, Ltab on test level of significance $\alpha=0,05$ obtained 0,220 which is bigger than Lo. It means the resulted score distributed normally. The result of smash (Y), Lo score $=0.1133$ with $n=15$, Ltab on test level of significance $\alpha=0,05$ obtained 0,220 which is bigger than Lo. It means the obtained score distributed normally. From the explanation above, all variables were spread normally since each variable has lower Lo score than Ltab on test level of significance $\alpha=0,05$. After doing a test analysis requirement, the data of each variable are worthy for hypothesis testing. It can be done by using simple correlation and multiple correlation formulas. It can be seen in the discussion below for further explanation.

\section{HYPOTHESIS TESTING}

\section{Hypothesis One}

Hypothesis one which proposed in the study showed there was a significant relationship between muscle explosive power with the smash of $P B$. Hamparan Sungai Penuh players. The summary of simple correlation the analysis described on the table below: The result of the table above showed a significant correlation between arm muscle explosive power $\left(\mathrm{X}_{1}\right)$ with smash variable (Y), it assumed that statistical analysis obtained $r$ count on 0,733 and $r$ table on level $\alpha=0,05$ is 0,641 . Whereas, $r$ count $(0,733)>r$ table $(0,641)$ then $t$ count $=5,71>\mathrm{t}$ table $=1.76$. Therefore, Ho $($ showed no correlation) rejected and $\mathrm{Ha}$ (showed correlation) accepted. It showed correlation coefficiency between arm muscle explosive power $\left(\mathrm{X}_{1}\right)$ with smash $(\mathrm{Y})$ stated there was a relationship which meant accepted.

\section{Hypothesis Two}

Hypothesis two proposed in the study performed there was a significant relationship between leg muscle explosive power $\left(\mathrm{X}_{2}\right)$ and smash $(\mathrm{Y})$ of $\mathrm{PB}$. Hamparan Sungai Penuh players. The summary of simple correlation analysis described in the table below: The result of the table above showed there was a significant relationship between leg muscle explosive power $\left(\mathrm{X}_{2}\right)$ to smash $(\mathrm{Y})$, it implied that statistic analysis obtained $r$ count 0,713 and $r$ table on level $\alpha=0,05$ are 0,641 . Therefore, $\mathrm{r}$ count $(0,713)>\mathrm{r}$ table $(0,641)$ then $\mathrm{t}$ count $=5,23>\mathrm{t}$ table $=$ 1.76. It showed that Ho (stated no correlation) rejected and $\mathrm{Ha}$ (stated correlation) accepted. It means correlation coefficiency between arm muscle explosive power $\left(\mathrm{X}_{2}\right)$ with smash variable (Y) stated there is a correlation which is accepted.

\section{Hypothesis Three}

Hypothesis three which proposed in the study performed there was a significant correlation between hand-eye correlation with the smash of $P B$. Hamparan Sungai Penuh players. The summary of the simple correlation analysis described on the table below:
The result of the table above showed there was a significant relationship between hand-eye coordination $\left(\mathrm{X}_{3}\right)$ to smash $(\mathrm{Y})$, it implied that statistic analysis obtained $r$ count 0,661 and $r$ table on level $\alpha=0,05$ are 0,641 . Therefore, $r$ count $(0,661)>r$ table $(0,641)$ then $t$ count $=4,23>\mathrm{t}$ table $=1.76$. It showed that Ho $($ stated no correlation) rejected and $\mathrm{Ha}$ (stated correlation) accepted. It means correlation coefficiency between hand-eye coordination $\left(\mathrm{X}_{3}\right)$ with smash variable $(\mathrm{Y})$ stated there was a correlation which was accepted.

\section{Hypothesis Four}

Hypothesis four which proposed on the study performed there was a significant correlation among arm muscle explosive power, leg muscle explosive power, and hand-eye correlation toward the smash of $P B$. Hamparan Sungai Penuh players. The summary of simple correlation analysis described on the table below: The result of the table above showed there was a significant relationship between arm muscle explosive power $\left(\mathrm{X}_{1}\right)$, leg muscle explosive power $\left(\mathrm{X}_{2}\right)$, and hand-eye coordination variable $\left(\mathrm{X}_{3}\right)$ to smash $(\mathrm{Y})$, it implied that statistic analysis obtained $\mathrm{r}$ count 0,838 and $\mathrm{r}$ table on level $\alpha=0,05$ are 0,641 . Therefore, $r$ count $(0,838)>r$ table $(0,641)$ then $\mathrm{t}$ count $=8,67>\mathrm{t}$ table $=3,98$. It showed that Ho (stated no correlation) rejected and $\mathrm{Ha}$ (stated correlation) accepted. It means correlation coefficiency among arm muscle explosive power $\left(\mathrm{X}_{1}\right)$, leg muscle explosive power $\left(\mathrm{X}_{2}\right)$, and hand-eye coordination $\left(\mathrm{X}_{3}\right)$ toward smash variable $(\mathrm{Y})$ stated there was a correlation which was accepted.

\section{DISCUSSION}

The relationship between arm muscle explosive power $\left(X_{1}\right)$ toward the smash of PB. Hamparan Sungai Penuh players

Based on the study conducted on the field, it showed that there was a relationship between arm muscle explosive power $\left(\mathrm{X}_{1}\right)$ toward the smash (Y) of $P B$. Hamparan Sungai Penuh players. It was proven by the result of $r$ count on 0,733 and $r$ table on level $\alpha=0,05$ is 0,641 . Whereas, $r$ count $(0,733)>r$ table $(0,641)$ then $t$ count $=5,71>\mathrm{t}$ table $=1.76$. The result of the study must be concerned seriously by coach or badminton players well since the study showed the element of arm muscle explosive power training must be developed on a training program which is done by players in the field. Generally, based on the fact in the field, the coach only prioritized on techniques, tactics, and strategies. Thus, the badminton players inclined to train themselves on their techniques, tactics, and strategies, which means the coach or players ignored the importance of physically condition in developing trained techniques, tactics, and strategies. the element of physic condition which needed training on the study was arm muscle explosive power since it has close relation toward the smash. As we know that muscle explosive power is the physical condition elements, which means its ability to use the muscle to receive a burden 
while working. If it relates to the arm muscle explosive power which explains the ability of arm muscle to use the muscle receiving burden while working.

The explosive power relates to power. Arm muscle explosive power needs to train to increase the smash in badminton, without training arm muscle explosive power, the players feel difficult to increase their smash accuracy. So, the players can not do better smash in the competition.

The relationship of leg muscle explosive power $\left(\mathrm{X}_{2}\right)$ toward the smash (Y) of PB Hamparan Sungai Penuh players.

Based on the study conducted on the field, it showed that there was a relationship between leg muscle explosive power $\left(\mathrm{X}_{2}\right)$ toward the smash (Y) of $P B$. Hamparan Sungai Penuh players. It was proven by the result of $r$ count 0,713 and $r$ table on level $\alpha=0,05$ are 0,641 . Therefore, $r$ count $(0,713)>r$ table $(0,641)$ then $t$ count $=5,23>\mathrm{t}$ table $=1.76$. The result of the study must be concerned seriously by coach or badminton players well since the study showed the element of leg muscle explosive power training must be developed on a training program which is done by players in the field. Generally, based on the fact in the field, the coach only prioritized on techniques, tactics, and strategies. Thus, the badminton players inclined to train themselves on their techniques, tactics, and strategies, which means the coach or players ignored the importance of physically condition in developing trained techniques, tactics, and strategies. the element of physic condition which needed training on the study was leg muscle explosive power since it has close relation toward the smash.

Leg explosive power is a muscle ability to overcome the burden of resistance with a high contraction speed. Leg muscles have very strong explosive power that it is required to do the smash in badminton because a good leg muscle explosive power will determine the good quality of the smash. Those physical elements are the product of strength and speed ability. The explanation above explained that the better leg muscle explosive power will release a good smash which has a good and quick push. It makes the players are easy to make a good smash in badminton. Therefore, the players have to do motoric training continuously, programmed, and discipline to have reliable leg muscle explosive power in doing the smash. The explanation above concluded that leg muscle explosive power training can increase the ability of smash for the coach and players, especially in pushing and jumping position as the result of wellprogrammed, continuous, and directed training.

The relationship of hand-eye coordination toward the smash of PB. Hamparan sungai penuh players.

Based on the study conducted on the field, it showed that there was a relationship between hand-eye coordination $\left(\mathrm{X}_{3}\right)$ toward the smash (Y) of $P B$. Hamparan Sungai Penuh players. It was proven by the result of $r$ count 0,661 and $r$ table on level $\alpha=0,05$ are 0,641 . Therefore, $r$ count $(0,661)>r$ table $(0,641)$ then $t$ count $=4,23>\mathrm{t}$ table $=1.76$. The result of the study can be the consideration for the coach or players of badminton to develop hand-eye coordination training which done in the field to increase smash quality.

Coordination is a working process of muscle which releases a directed and well-structured movement. It aims to form some movements needed in the skilled technique. The better the coordination from some movement elements, the better the movement released. It implies that good coordination is required to master a good technique of movement. By having good hand-eye coordination in the smash, the badminton players will have good, accurate, and fast smash which will support the players to get more the point in badminton. The explanation above showed that hand-eye coordination training can increase the ability of the smash for coach and players which done regularly, continuously, and discipline.

The relationship of arm muscle explosive power $\left(\mathrm{X}_{1}\right)$, leg muscle explosive power $\left(\mathrm{X}_{2}\right)$, and hand-eye coordination $\left(\mathrm{X}_{3}\right)$ toward the $\operatorname{smash}(\mathrm{Y})$ of $\mathrm{PB}$. Hamparan players.

Based on the study conducted on the field, it showed that there was a relationship among arm muscle explosive power $\left(\mathrm{X}_{1}\right)$, leg muscle explosive power $\left(\mathrm{X}_{2}\right)$, hand-eye coordination $\left(\mathrm{X}_{3}\right)$ toward the smash $(\mathrm{Y})$ of $P B$. Hamparan Sungai Penuh players. It was proven by the result of $r$ count 0,838 and $r$ table on level $\alpha=0,05$ are 0,641 . Therefore, $r$ count $(0,838)>r$ table $(0,641)$ then $t$ count $=8,67>t$ table $=3,98$. The result of the study can be the consideration for the coach or players of badminton to develop the three elements training which done in the field to increase smashes quality. The study proved that there was a significant correlation among arm muscle explosive power, leg muscle explosive power, and handeye coordination toward the smash. Generally, based on the fact in the field, the coach only prioritized on techniques, tactics, and strategies. Thus, the badminton players inclined to train themselves on their techniques, tactics, and strategies, which means the coach or players ignored the importance of physically condition in developing trained techniques, tactics, and strategies. Therefore, the study conducted to increase the smash accuracy of the badminton players.

"The smash can be done in silence/stand or jumping smash." The players should learn to master all hit techniques of smash perfectly. The advantage is useful to increase the game's quality. The smash has a crucial role to position the shuttlecock on the opponent's area and get the point. The smash is an ability of the badminton players to direct shuttlecock to the certain target so that the shuttlecock is hard to bring back. The explanation above 
emphasized that a good smash will give an easy point for players to create a victory in every game. Whereas the players should train their motoric training continuously to get a good smash by exercising the arm muscle explosive power, leg muscle explosive power, and hand-eye coordination continuously, programmed, and discipline.

\section{CONCLUSION}

Based on the study conducted in the field, the researcher concluded: (1) there was a relationship between arm muscle explosive power $\left(\mathrm{X}_{1}\right)$ toward the smash $(\mathrm{Y})$ of $P B$. Hamparan Sungai Penuh players. It was proven by the result of $r$ count on 0,733 and $r$ table on level $\alpha=0,05$ is 0,641 . Whereas, $r$ count $(0,733)>r$ table $(0,641)$ then $t$ count $=5,71>\mathrm{t}$ table $=1.76$. (2) there was a relationship between leg muscle explosive power $\left(\mathrm{X}_{2}\right)$ toward the smash (Y) of $P B$. Hamparan Sungai Penuh players. It was proven by the result of $\mathrm{r}$ count 0,713 and $\mathrm{r}$ table on level $\alpha=0,05$ are 0,641 . Therefore, $r$ count $(0,713)>r$ table $(0,641)$ then $\mathrm{t}$ count $=5,23>\mathrm{t}$ table $=1.76$. (3) there was a relationship between hand-eye coordination $\left(\mathrm{X}_{3}\right)$ toward the smash (Y) of PB. Hamparan Sungai Penuh players. It was proven by the result of $r$ count 0,661 and $r$ table on level $\alpha=0,05$ are 0,641 . Therefore, $r$ count $(0,661)>\mathrm{r}$ table $(0,641)$ then $\mathrm{t}$ count $=4,23>\mathrm{t}$ table $=$ 1.76. (4) there was a relationship among arm muscle explosive power $\left(\mathrm{X}_{1}\right)$, leg muscle explosive power $\left(\mathrm{X}_{2}\right)$, hand-eye coordination $\left(\mathrm{X}_{3}\right)$ toward the smash $(\mathrm{Y})$ of $P B$. Hamparan Sungai Penuh players. It was proven by the result of $r$ count 0,838 and $r$ table on level $\alpha=0,05$ are 0,641 . Therefore, $r$ count $(0,838)>r$ table $(0,641)$ then $t$ count $=8,67>\mathrm{t}$ table $=3,98$.

\section{REFERENCES}

[1] Undang-Undang RI Nomor 3 Tahun 2005 Tentang Sistem Keolahragaan Nasional. 2005, pp. 20.

[2] Maidarman. "Ilmu Melatih Lanjutan". Padang : FIK UNP. 2010, pp. 23.

[3] M. Dinata. "Bulu Tangkis". Jakarta: PT.Cerdas Jaya. 2006, pp. 56.

[4] A. Suharsimi. "Prosedur Penelitian". Jakarta: Rineka Cipta. 1996, pp. 45

[5] Donie. "Pembinaan Bulutangkis Prestasi". Padang: Wineka Media, FIK UNP. 2009, pp. 12.

[6] Zarwan. "Bulu tangkis Dasar". Padang: Suka Bima Press. 2009, pp. 56.

[7] Tohar. "Olahraga Pilihan Bulutangkis". Departemen Pendidikan dan Kebudayaan Direktorat Jenderal Pendidikan Tinggi Proyek Pembinaan Tenaga Kependidikan, 1992, pp. 23.

[8] Arsil. "Pembinaan Kondisi Fisik". Padang: Suka Bina, FIK UNP. 2009, pp. 50-52. 